\title{
Linguistic Politeness: An Analysis of Gender Differences in Speaking Classroom
}

\author{
Syafrizal Syafrizal 1, Fianika Sya'bana Putri² \\ Universitas Sultan Ageng Tirtayasa \\ syafrizal@untirta.ac.id¹, fianika.s@yahoo.com²
}

\begin{abstract}
The aim of research was to explore whether there is any linguistic politeness through gender differences in speaking classroom. Communicative competence underlines that grammatical knowledge is not enough to interact adequately, thus it includes pragmatic skills. For example, several communication errors, for confusion, may take place without logical understanding. Furthermore, politeness is an essential component of pragmatic competence. Many works have been carried out in this area, but few have shown the differences between the linguistic politeness of the language of male and female in the speaking classroom, while its primary findings are statements. Such work is carried out in the speaking classroom of university students, in particular in the sense of global foreign affairs. The statement is based on the Bacha, Bahous \& Diab (2012). The researchers used qualitative research through observational method, all the conversation in classroom were displayed and categorized to observe data. In addition, certain politeness hypotheses are used to interpret the results. The studies have shown that females are more respectful than male students in general. In conclusion, teachers comprehend this reality since they do not require male students to be as respectful as females, they are practically peculiar.
\end{abstract}

Key words: gender differences, linguistic politeness, pragmatic, communicative competence

\section{INTRODUCTION}

The emergence of English education in Indonesia is obvious in which English is taught to young learners earlier even before they went to school. The EFL students should be able to master four skills in English language instruction. They chat, hear, listen and compose in English (Syafrizal \& Haerudin, 2018).Moreover, their ability to achieve their goals in schools largely depends on their speaking skills that illustrate how inadequate grammatical information is to talk or to interact in a certain language. Speakers in multilingual culture use multiple languages, sometimes bilingualism, while communicating (Syafrizal, S. Et al., 2019). Therefore, other information is required, namely logical, to be able to 
interact entirely. The EFL students tend to be pragmatics. Basically, pragmatic is "the recognition that the individual is speaking decides what the speaker says and understands the deliberate power conveyed through implicit attitudes" (Kreidler, 1998). There are instances without this competence in which the speaker and the interlocutor(s), even communication failures, can't understand each other. One significant dimension of strategic skill across more specific fields is diplomacy, which implies "the manifestation of the purpose of the speakers to reduce the risks faced us through such face-threatening actions".

Politeness has also been studied for decades as an essential component of strategic maturity, communicative competence. In particular, several scholars have investigated the connection between politeness and gender. The work was performed in academic and non-academic contexts. However, after the findings of the academic research have been closely checked, the researcher makes account at some of the same points. First, several of them were performed in a general classroom in English, not in a speaking classroom where plentiful words are found. Thus, this void is filled through work in the speaking classroom by this research.

Second, the results of the studies indicate that the language of women is more general than male. In contrast, the findings of researchers showed that female linguistic politeness is generally significantly different from gender to woman, since female were more respectful in relation with male (Tannen, 1990; Weather, 1997; Brown, 1980; Lorenzo-Dus \& Bou-Franch, 2003; Bacha, Bahous \& Diab, 2012; Alavi, Moradi \& Taggaddomi, 2013). The researcher is therefore quite curious about the degree of politeness in classrooms between female and male, particularly in international program students, who speak English widely but are not native speakers. Finally, few researchers have examined the question of linguistic politics in the language classroom in depth for the best knowledge researchers. Because of those reasons, the objective of this research brings this exploration hole by directing an examination under the title "Linguistic Politeness: An Analysis of Gender Differences in Speaking Classroom", and responding to the inquiry "who is progressively well polite among male and female?"for further, the researchers were supposed to find out the difference thing occurred in communication based on gender

\section{ENGLISH EDUCATION}

Journal of English Teaching and Research 


\section{Linguistic Politeness}

Throughout an encounter, politeness can be described as a behaviour of people displaying their consciousness of the identity of others. Whereas, this sort of disposition is rendered by verbal communication. Linguistic friendly,for instance, whenever anyone speaks, her words can influence the face of the speaker in different ways. The result can, for example, be positive or negative. Linguistic politeness will also be recognized by speakers in order to prevent contact issues. Linguistic politeness, in other terms, is a realistic politeness strategy because "linguistic politeness was intended to seek to establish a broadly functional paradigm, an account of how language is used in conversation" (Fauziati 2016).

In precise words, linguistically being respectful not only refers about others, but also takes them into consideration (Yule, 2006). This means that the speaker will in fact use her linguistic politeness knowledge, as she realizes that each word she says will have an effect on others.It means that the politeness will occur when on in the situation of the following things such as, discussion create, preserve, and defend the identity" (Richards, 2013). Being respectful is important in conversation as respecting the feeling of others would build degrees of shared satisfaction and promote ties between speakers (Keikhaie \& Mozaffari, 2013).

\section{The Importance of Linguistic Politeness in Classroom}

Generally, in international language teaching, cultural history assumes a critical position (Abertova, 2012). This is obvious because a language classroom is a place where language and communication can be learned. The dimensions of connectivity have meanwhile been empirically apparent both in relational and transactional terms (Garces-Conejos \& Sanchez-Macarro, 1998; Torbelanca-Lopez \& Garces-Conejos, 1997). Interactional conversation functions to lubricate social roles and relationships, to consolidate and confirm relationships and to express solidarity or empathy. Transactional communication would also have the function of encouraging someone to do things or affecting the actions of others according to speakers' standards (Kristina, 2014). They are also important for second-language students to be understood. In order to encourage sociopragmatic comprehension, 
and to enhance the development and interpretation of the pragmalinguistic (BouFranch \& Garces - Conejos, 2003; Garces - Conejos \& Sanchez - Macarro, 1998), speakers must also consider the linguistic choices produced in their specific contexts.

Learners also conduct speech actions like apologies, denial and demands as a result of realistic transition in accordance with sociolinguistic norms in their mother tongue. For example, students often ask apologies at the end of their speech in the researcher 's classroom, which are not suggested for English. This trend is affected by the Indonesian tradition such as when one asked forapologises. International language instruction will thus get used to a realistic method. Teachers of foreign languages will go above the pure grammar and time introduction only. To adapt them to the sociological framework of relations between the interlocutors of the target language, linguistic models must be contextualised and related with the actual condition of use. The theory of language politics offers adequate tools to teach language forms in the context. Secondspeaking learners should not only be able to articulate their messages in a proposal but also to fulfill the social criteria, because failure to fulfill social specifications will contribute to either strategic failure (Thomas, 1995) or even contact collapse. Linguistic politeness is used as part of a set of rational laws that discourage contact. It is further developed to mitigate frictions in the relationship of individuals (Fauziati, 2016).

\section{Gender and Linguistic Politeness}

Many studies in the field of gender and linguistic politeness find that male and female in fact are linguistically politely different. Male as masculine as linguistically as female may be understood. Furthermore, male and gender are distinct from conversational conventions (Coulmas, 2005). Holmes also described female expression in Lorenzo-Dus as more courteous than male expression (Lorenzo-Dus and Bou-Franch, 2003). Labov and Trudgill in Brown have agreed that women-men are more respectful as females-males usually use grammar hypercorrect as they talk (Brown, 1980). This is an appropriate outcome. Hence, the usage of large proportion of structured types is known as more formal than male voice. In 1980, Brown has studied this trend and observed that it appears 
intuitively prudent to assume that Females' talk is considered respectfully and appropriately when they were in the situation of secondary status in comparison to males' talk and because that condition of being inferior is also considered as higher standards of politeness (Brown, 1980). The example of difference between men and women is clear when you use the partial suffix for words like walking, running, and jogging. In contrast, it is considered more standard and prestigious based on numerous surveys (Coulmas, 2005).

It is therefore necessary to note that a woman is representative of the community of speakers, not of people, for equal usage of criteria or reputation variants. Both males and females, they do not speak as a representative of women and male only; yet they could be as teachers and students, friends and strangers, employees and employers, as ethnic members, as religious communities andmany more personalized capacities.

Finally, female individuals have a greater chance of expressing positive politeness than male individuals and of using attenuating strategies to prevent or minimize the threat to their contact person (Lorenzo-Dus \& Bou-Franch, 2003). In other words, when a woman speaks, she takes account of her interlocutor 's feelings and will try not to lose her face.

\section{METHOD}

The researchers used qualitative research through observational method. It was conducted in thesubjectspeaking.The number of the respondence chosen randomly,were 16 students in the third year, made up of 10 females and 6 males. Students of English Education are selected because they are considered to be more fluent English speakers than other levels in public relations, so the researcher aims to minimize the number of English speakers. The researchers also collected the data trough observation and interview to support the triangulation of data. This researchfocused on human behaviour, process and natural phenomena. The observational method of this study is non-participatory observation. Nonparticipatory evaluation means that without intervention, researchers attend the class. Bacha, Bahous \& Diab (2012) have adapted theobservation sheet to address three situations that have to be observed. The following are the three situations: 
(1) Students who come late to class and as a result of that, (2) respond to questions in school by teachers and (3) students who do notcome and listen to lecturer. In addition, the data were evaluated from those three cases with Brown \& Lavinson and Lakoff's politeness theories. In addition, some previous authors boost the analyses. The writer even recorded it with a video camera.

\section{RESULTS}

\section{Focuses on a student coming late to the classroom}

There were six students cominglate to the school, four females and two males' students. Not all the students knocked at the door, even they did not ask for authorization or excuses. The schools' teacher says that you do not have to do it and you do not have to apologize until it is 15 minutes from the beginning of the class.

- At 2 minutes and 36seconds, two female students arrived late, both of them did not greet the teacher but sat directly on their chair and followed the class. They did not talk to each other, or' say hi' to friends next to them.

- At 4 minutes and 14 seconds, the male student arrived and sat directly on his chair, then at 5 minutes 7 seconds to 5 mins 46 seconds, he talked to his friend.

- At 7 minutesand 6 seconds, the male student came and sat directly on his chair, then at 7 minutes and 35 seconds to 8 minutes and54 seconds, he talked to a friend next to him, even his body language looked like hewas trying to ignore the teacher.

- At 12 minutes and 8 seconds, the female student came before he sat and shake the teacher's hand.

- At 13 minutes and12 seconds, the female student came late and sat directly on her chair. She responded to the teacher's comment at 13 mins 21 secs.

From the description of perception above, it tends to be presumed that in delay circumstance female were viewed as increasingly neighbourly then male. It is very well seen when one of females' understudy welcomes the educator by shaking teacher's hand which is socially respectful in Indonesia. This is in accordance with Earthy coloured and Lavinson (1987) who uncovered that consideration procedures are affected by social practices. Furthermore, other two female understudies legitimately follow the class, even one of them straightforwardly

\section{ENGLISH EDUCATION}

Journal of English Teaching and Research 
follow instructor's movement by reacting to her utterances. In an unexpected way, two male understudies talk with companions close to them before follow the class exercises, besides one of them is looked overlooking the instructor from his nonverbal communication. What guys do are disregard the educator as well as occupy companions' focus.

\section{Focuses on Answering Questions from Teacher in The Classroom}

- At 12 minutes and 30 secs, there were four students who address her to remember the information from the previous conference. The four people and four females. Three males. The teacher is cut off by one male student and asks the query explicitly, while another one also lifts its head.

- At 21 minutes and 43 seconds, the teacher asked the class to divide the group, the only student were answering her was female, though she did not raise her hand first.

- At 34 minutes and 29 seconds, the student reacts to the teacher's question by lifting her first hand. She says "I will do what Dinda did. If I am the parent, I will let my children learn how to utilize the new technologies and call them".

- At 43 minutes and 11 seconds, the student attempted to address the query of the teacher, but at 44 minutes and 9 seconds, the student cut her off and asked, "What is it?". The female stopped for some time and she was looked making a decent attempt to disregard him by proceeding with her announcement. Shockingly the male student cuts again at 44 mins 32 secs by saying "Yes... yes..., however what is that?"

- At 47 minutes and 48 seconds, there was a male student responded to educator's inquiry. At the outset, he talked smoothly, anyway he frequently coded changing to Bahasa Indonesia like Pelaku (practitioner), hukum (law), putus asa (surrender), and so on.

From the observation it is possible to infer that female students are normally more respectful than male students and address the query. Firstly, two females raise up their hand and just one male lift up their hand. Hand raising is a symbol that the Indonesian community, mostly created by a female, needs permission. Bacha, Bahous \& Diab (2012) backed this by suggesting that female are more respectful than male, who are connected to the cultural element. Secondly, at 34 
mins 29 secs, the students said, '...I will do what Dinda did...' as she says, Dinda shows what Lakoff called a friendly theory (Fauziati, 2016). Lakoff has also shown that the second rule, namely, to be polite, contains three points which are not necessary, give an option and be friendly. In addition, the call by a friend's name is an indicator of being friendly. Thirdly, on the basis of the assessment, two male students break off some words, for example in a 13 mins 28 secs where male students break the lecturer. When the female student has their thoughts, the male student is interrupted by 44 mins 6 secs and 44 mins 26 secs respectively. In addition, when a male student expresses his opinion, the language is transferred to Bahasa Indonesia, and the formality of his expression is diminished as a result. Speech is recognized by the use of a high proportion of the standard forms as polite if it is more formal (Brown, 1980).

\section{Focuses on Students Who Do Not Pay Attention to Class Lectures due to Communicating Among Themselves}

In light of the perception, there is no huge distinctive among male and female understudies on account of not focusing on the class address because of talking among themselves. For the most part the understudies who sit close to the instructor will give more consideration contrasted with the individuals who sit a long way from the educator. After the educator partitions class into certain gatherings, the guest plan is changed becomes:

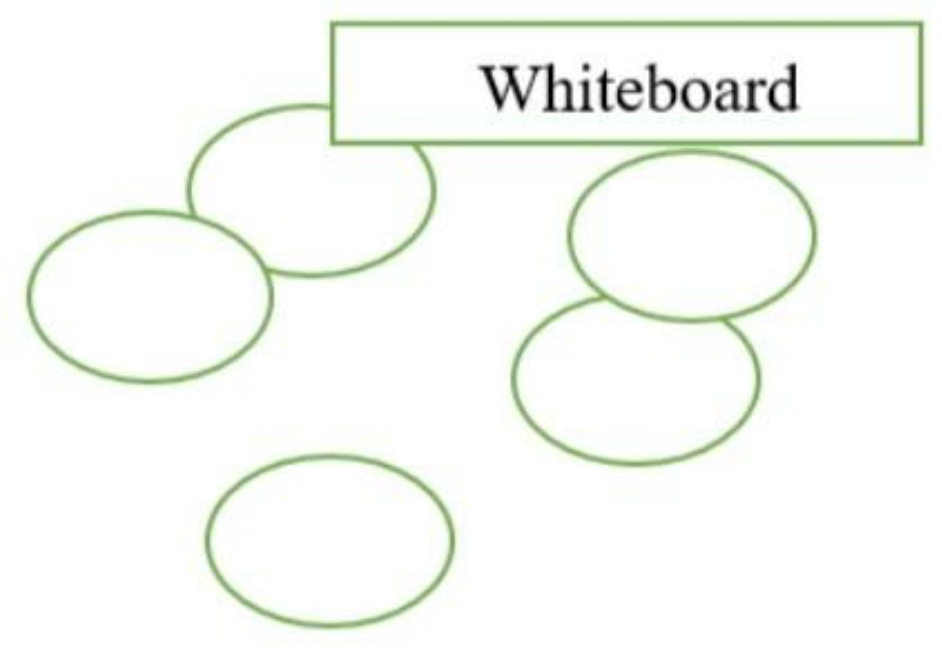

Pict.1Teachers separatethe class into certain groups

\section{ENGLISH EDUCATION}

Journal of English Teaching and Research 
For instance when the teacher is in group 1, students who centre in focusing on her is just students of group 1, students of group 2 is looked setting up their task increasingly genuine contrast with group 4 and 5 , at that point understudies of group 3 do not begin their venture yet talking among themselves even laugh.

\section{CONCLUSION}

The researchers finally conclude that there were three conditions are distinguished by the specialist from the investigation. Those two of the three circumstances show that there is a critical distinction between phonetic legislative issues among people, while the last circumstance shows that there are no significant contrasts among people. Cameron and Coulmas (2005), who all react to the differences among male and female verbal amenability, acknowledge the differentiations between the two. In rundown, ladies are more gracious than men. This is in accordance with the Lorenzo-Dus (2003) Holmes, and the Earthy coloured Labov and Trudgill (1980).In any case, since politeness and impoliteness are such a great amount of associated with convention, the result of this work won't be worthy to different nations with explicit societies. In addition, all articulations among people cannot be summed up in light of the fact that male and female communicate not just as male and female but as understudies, educators, businesspeople and customers, specialists and patients, and so forth. The result isn't restricted to all articulations.

\section{REFERENCES}

Abertova, a. (2012). Aspects of politeness in a classroom of English as a second language. Prague: Charles university in Prague.

Alavi, T., Moradi, S., \& Taggaddomi, M. S. (2013). Difference(s) between Male and FemaleSpeakers Turkish Regarding Politeness Norms. Journal of Language Teaching and Research, 1332-1337.

An, Q. (2009). An Empirical Study Based on College English Teaching with theBackground of Networks. Computer-Assisted Foreign Language Education, 3,58-62.

Bacha, N. N., Bahous, R., \& Diab, R. L. (2012). Gender and Politeness in a Foreign Academic Context. International Journal of English Linguistics, 79-96.

Brown. (1980). How and why are women more polite: some evidence from a Mayan community. In B. McConnel-Ginnet, Women and language in literature and society (pp. 111-136). Oxford: Blackwell.

Climate. (1997). Men and Women talking: the differential use of speech and language by gender. London: Routledge.

Coulmas, F. (2005). Sociolinguistics the Study of Speakers' Choice. New York: Cambridge University Press.

Fauziati, E. (2016). Applied Linguistics Principles of Foreign Language Teaching, Learning, and Researching. Surakarta: Era Pustaka Utama.

Fraser. (1983). The Domain of Pragmatics. In J. Richards, \&Schmidt, Language and Communication (pp. 29-59). New York: Longman. 
Garces-Conejos, P., \& Sanchez-Macarro. (1998). Scientific Discourse as An Interaction: Scientific Articles vs Popularizations. Linguistics Choices Across Gender, 173-190.

Garces-Conejos, P., \& Torbelanca-Lopez, M. (1997). Emphasis and mitigation strategies in the speech of non-native English teacher. Grammar and Pragmatic, 113.

Keikhaie, Y., \& Mozaffari, Z. (2013). A Socio-linguistic Survey on Females' Politeness Strategies in the Same Gender and in the Cross-Gender Relationship. Iranian Journal of Applied Language Studies, 51-82.

Kreidler, Charles W; Introducing English semantic s (1998)

Lorenzo-Dus, \& Bou-Franch. (2003). Gender and Politeness: Spanish and British Undergraduate Perception of Appropriate Request. In Santa Emilia, Genero, lenguaje y traduccion (pp. 187-199). Valencia: Universitat de Valencia.

Mills, S. (2003). Gender and Politeness. Cambridge: Cambridge University Press.

Nemati, A., \& Bayer, J. M. (2007). Gender Differences in the Use of Linguistic Forms in the Speech of Men and Women: A Comparative Study of Persian and English. International Journal of Applied Linguistic, 185-201.

Richards, S. (2013). Longman Dictionary of Language Teaching and Applied Linguistics. New York:Routledge.

Rosetti, P. (1998). Gender Differences in E-mail Communication. The TESL Journal, $4(7), 1-6$.

Ryoo, Hye-Kyung. (2005). Achieving friendly interactions: A study of service encounters between Korean shopkeepers and African-American customers. Discourse and Society. V (16) : 79-105.

Syafrizal\& Haerudin. (2018). THE IMPLEMENTATION OF VOCABULARY BUILDING STRATEGY IN TEACHING ENGLISH VOCABULARY TO YOUNG LEARNERS.Journal of English Language Teaching, 2 (1), 41-48.

Syafrizal, S. et al. (2019).INDONESIAN TEACHER'S CODE SWITCHING AND MIXING IN EFL CONTEXT. English Language Teaching and Linguistics Studies, 1 (1).http://dx.doi.org/10.22158/eltls.v1n1p1

Steele,S., Tanz, C. (2002).Language, Gender and Sex in Comparative Perspective.Cambridge: Cambridge University Press.

Tannen. (1990). You just don't understand: Women and men conversation. New York: William Marrow.

Thomas, J. (1995). Meaning in Interaction. London: Longman.

Yule, G. (2006). The Study of Language (3rd ed). Cambridge: Cambridge University Press. 